University of Nebraska - Lincoln

DigitalCommons@University of Nebraska - Lincoln

April 1994

\title{
Determining the Breadth of Leadership and Human Resource Management/Development Offerings in Post-Secondary Departments of Agricultural Education
}

\author{
F. William Brown \\ University of Nebraska - Lincoln \\ Susan Fritz \\ University of Nebraska - Lincoln, sfritz1@unl.edu
}

Follow this and additional works at: https://digitalcommons.unl.edu/aglecfacpub

Part of the Other Public Affairs, Public Policy and Public Administration Commons

Brown, F. William and Fritz, Susan, "Determining the Breadth of Leadership and Human Resource Management/Development Offerings in Post-Secondary Departments of Agricultural Education" (1994). Faculty Publications: Agricultural Leadership, Education \& Communication Department. 14. https://digitalcommons.unl.edu/aglecfacpub/14

This Article is brought to you for free and open access by the Agricultural Leadership, Education \& Communication Department at DigitalCommons@University of Nebraska - Lincoln. It has been accepted for inclusion in Faculty Publications: Agricultural Leadership, Education \& Communication Department by an authorized administrator of DigitalCommons@University of Nebraska - Lincoln. 


\title{
Determining the Breadth of Leadership and Human Resource Management/Development Offerings in Post-Secondary Departments of Agricultural Education
}

\author{
F. William Brown, Associate Professor \\ Susan M. Fritz, Instructor \\ University of Nebraska
}

As early as 1976, the mission of vocational and technical agricultural education included the charge for educators "to develop the abilities needed to exercise and follow effective leadership in fulfilling occupational, social and civic responsibilities" (United States Office of Education, 1976, p. 4). In 1989 the Strategic Plan for Agricultural Education reiterated this objective in Goal 3: "To amplify and expand the "whole person' concept of education, including leadership, personal and interpersonal skills," (National Summit on Agricultural Education, 1989, p. 4).

In some institutions the offering of leadership and human resource management/development courses by postsecondary agricultural education departments have fanned-out beyond departmental majors to include students from across the college and the institution (Foster and Dodge, 199 1). Despite acceptance by the profession that it is the charge of agricultural education to provide leadership and human resource management/development (HRM/D) instruction and conventional wisdom that course offerings in this area have been widespread and successful, research had not been conducted at the post-secondary level to determine the precise breadth and nature of such offerings. The purpose of this study is to ascertain the actual nature and circumstances of these activities.

\section{Objectives} determine:

The objectives of the study were to

The extent to which post-secondary agricultural education departments offer leadership and HRM/D courses.
The enrollment history of leadership and HRM/D courses in post-secondary agricultural education departments.

The characteristics of faculty who teach leadership and HRM/D courses in postsecondary agricultural education departments.

Student, departmental faculty and college faculty attitudes toward leadership and HRM/D courses offered through postsecondary agricultural education departments.

\section{Procedures}

Population

Using the 1991- 1992 Directory of Teacher Educators in Agriculture compiled by David C. Whaley, Colorado State University, and crossreferenced with the 1992 Agricultural Educators Directory, all departments in four-year postsecondary institutions whose departmental title contained the words "agricultural education" were identified. A total of 58 departments were identified using this criteria. This study population was subsequently reduced to 55 by deleting departments located outside of the United States or departments no longer in existence or no longer offering agricultural education courses.

Instrumentation and Data Collection

A single survey instrument, which solicited statistical data and faculty and student attitudes in regard to leadership and HRM/D courses offered by a department of agricultural education, was prepared. The instrument was reviewed by three current or former agricultural education department heads who made recommendations in regard to 
instrument validity. The survey instrument was mailed to the chairs or department heads in the population of interest. All 55 surveyed departments returned usable instruments (a 100\% response rate).

\section{Results}

\section{Extent of Current Offerings}

Respondents were asked if courses "which primarily deal with leadership and human resource management/development" were offered through their department of agricultural education. Thirtysix of the 55 respondents answered this question affirmatively. As noted in Figure 1, this represented 65 percent of all of the departments of agricultural education established and operating in the United States at the time of the study. Those responding affirmatively in regard to the offering of leadership or HRM/D courses were asked to provide course titles. Eighty-eight specific course titles were submitted. Of these, eight course titles were submitted, which described traditional teacher preparation courses rather than leadership and HRM/D offerings. These eight courses were not considered in the study. Their elimination had no effect on the calculation of the percent of agricultural education departments offering leadership and HRM/D courses. Although an imperfect indicator of content, the course titles provided reassurance that respondents had operationalized the concept of "leadership and human resource management/development" separately from agricultural education and teacher preparation course offerings.

\section{Enrollment Historv}

When asked the open-ended question regarding length of time each of the 80 leadership and HRM/D courses identified by respondents had been offered, responses ranged from less than one year to over 25 years. Some of the responses, particularly from departments with the longest lived courses, were submitted with the qualifier "approximately," thus compromising the accuracy of the calculated arithmetic mean of 10.5 years and other measures of central tendency $(\mathrm{SD}=8.25)$. As shown in Figure 2, a histogram representing a course longevity frequency distribution revealed what appears to be a tri-modal distribution. Thirtyeight percent of the courses had been in existence five or less years, 22.5 percent had been offered for more than five years but less than 11 years, 38.8 percent had been in existence more than 10 but less than 21 years, and 3.8 percent had been offered for more than 20 years.

A very substantial range was reported in regard to annual student enrollment in these types of courses. Several examples of low density courses, some with annual enrollment of as few as four students, were reported. On the other hand, one institution reported on their offering of an undergraduate course in "Interpersonal Skills for Agricultural Leadership" which sustains an annual enrollment of 720 students. The overall mean of 39.6 ( $\mathrm{SD}=91.5)$, is obviously distorted by these outliers making the median of 20 a better indicator of "typical" enrollment. Among the 36 institutions that offered leadership and HRM/D courses, 15 percent reported a dramatic increase in enrollment, 33 percent reported some increase, 50 percent reported stability, and two percent $(\mathrm{n}=\mathrm{l})$ reported some decline.

\section{Faculty Characteristics}

Ninety-five percent of the institutions offering these types of courses reported that they were taught by full-time faculty from the department of agricultural education. Ninety-two percent reported that the faculty of these courses held the rank of assistant professor or higher. A few departments reported the use of faculty from other departments, graduate assistants, instructors, or part-time faculty.

Fifty-six percent of respondents reported that these courses were taught by faculty with traditional agricultural education backgrounds. Thirty-three percent reported using faculty with traditional agricultural education backgrounds, but with "special preparation" in the area of leadership or management. Eleven percent $(n=4)$ of respondents reported using faculty without traditional agricultural education backgrounds, but with special preparation for teaching leadership.

Thirty-nine percent of the institutions that offered these types of courses had faculty whose assignment was primarily to teach leadership and HRM/D. Six institutions reported that they had hired faculty specifically to teach these courses in the department of agricultural education. Six respondents reported that in the future their institutions planned to hire faculty for the 
$(65.5 \%) \mathrm{N}=36$, Offer Courses

$(34.5 \%) \mathrm{N}=19$, Do Not offer Courses

Offer, $\mathrm{N}=3665 / 5 \%$

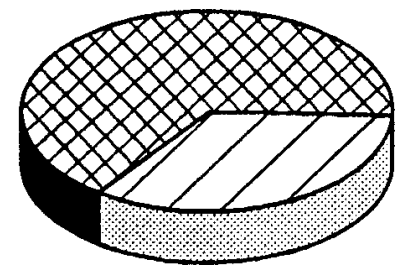

Do Not Offer, $\mathrm{N}=1934.5 \%$

Figure 1. Post Secondary Departments of Agricultural Education Offering Leadership/HRM Courses, $\mathrm{N}=55$

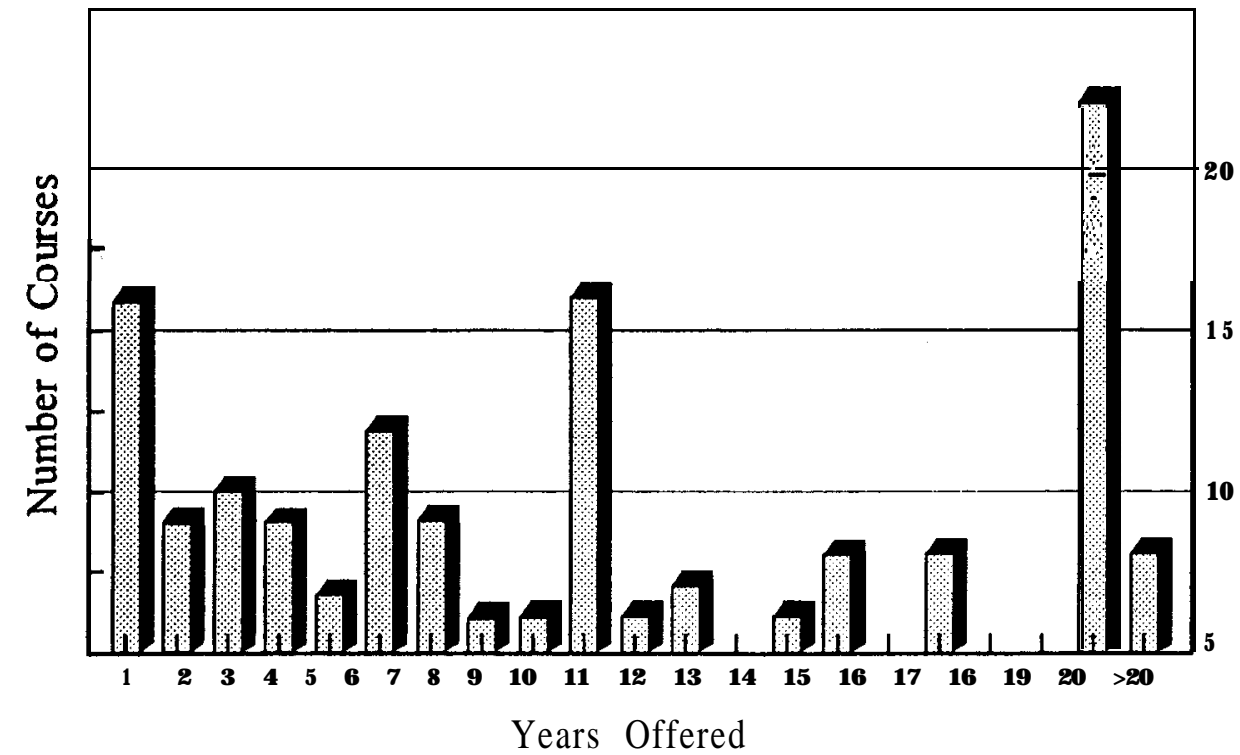

Figure 2. Number of Years Leadership/HIM Courses Have Been Offered, N=80 
department of agricultural education to primarily teach leadership and HRM/D.

\section{Student Reaction}

Of those departments offering leadership and HRM/D courses, 97 percent of respondents judged student attitudes toward their courses as either "extremely" or "moderately" positive. The remaining three percent felt that students were "ambivalent" toward these courses. When asked to compare their perception of student attitudes toward the leadership and HRM/D courses they offered to traditional agricultural education courses, 68 percent of the respondents judged them to be either "much more" or "somewhat more" positive, with all other responses assessing student sentiment as being "about the same." When asked to compare student attitudes toward the leadership and HRM/S courses offered through the department of agricultural education to all other courses offered at their institution, 86 percent of the respondents judged that sentiment as either "much more" or "somewhat more" positive. As in the previous case, the balance $(14 \%)$ considered student attitudes to be "about the same."

Table 1. Assessment of Student Reaction to Leadership HRM/D Courses Offered by Departments of Agricultural Education

\begin{tabular}{|c|c|c|}
\hline Descriptor & $\mathrm{N}$ & $\%$ \\
\hline Extremely & 18 & 50 \\
\hline Positive & 17 & 47 \\
\hline Ambivalent & 1 & 3 \\
\hline Moderately negative & 0 & 0 \\
\hline Negative & 0 & 0 \\
\hline
\end{tabular}

When asked to estimate to what extent students from outside the college of agriculture had taken leadership and HRM/D courses through the department of agricultural education, 22 percent of the respondents selected "frequently," 54 percent selected "occasionally," and 24 percent selected "almost never."

\section{Institutional Support}

Among agricultural education departments that offered leadership and HRM/D courses, 81 percent of the respondents judged faculty outside of their department as "extremely" or "somewhat" supportive of those courses. They reported 16 percent as being "ambivalent" and three percent as "somewhat skeptical and opposed." In terms of the agricultural education faculty itself, departments offering these types of courses reported 97 percent were either "extremely" or "somewhat supportive," with three percent (n=l) "ambivalent."

When asked to describe the process of obtaining approval to offer leadership and HRM/D courses, 53 percent of the respondents described the process as either "extremely easy" or "very easy." Thirty-one percent described the process as "neither easy or difficult" and 17 percent selected "difficult" as the most appropriate descriptor of the approval process. When asked to select sources of support for these course offerings, "our dean and other administrators" was identified 16 times, "individual influential faculty members" ten times, "alumni" seven times, "other departments in our college" four times, "members of our community" two times, "other colleges" one time and "other" unspecified sources four times.

Table 2. Assessed Student Reaction to Leadership HRM/D Courses Offered by Departments of Agricultural Education as Compared to All Other Courses Offered at the Reporting Institution

\begin{tabular}{lrr}
\hline Descriptor & $\mathrm{N}$ & \% \\
\hline Much more positive & 11 & 30 \\
Somewhat more positive & 20 & 56 \\
About the same & $\mathbf{5}$ & 14 \\
Somewhat more negative & $\mathbf{0}$ & 0 \\
Much more negative & 0 & 0 \\
\hline
\end{tabular}

Table 3. Attitudes of Nondepartmental Faculty to Leadership HRM/D Courses Offered by Departments of Agricultural Education

\begin{tabular}{lrc}
\hline Descriptor & $\mathrm{N}$ & $\%$ \\
\hline Extremely supportive & 10 & $\mathbf{2 8}$ \\
Supportive & 19 & $\mathbf{5 3}$ \\
Ambivalent & 6 & 16 \\
Somewhat skeptical and & & \\
opposed & 1 & $\mathbf{3}$ \\
Extremely opposed & 0 & $\mathbf{0}$ \\
\hline
\end{tabular}

\section{Discussion and Recommendations}

A previous contention, unsupported by data, that departments of agricultural education are actively-offering for-credit leadership and HRM/D courses is substantially confirmed in this study. Sixty-five percent of the 55 four-year, post- 
secondary agricultural education departments surveyed in this study reported that they offered courses of this type.

Data collected in the study strongly indicated that leadership and HRM/D courses offered through departments of agricultural education have been well received by students and faculty, have been established in general, without significant difficulty or opposition, and that enrollments are almost equally split between stability and growth.

Although well over half of the surveyed departments of agricultural education offered leadership and HRM/D courses, there appear to be substantial intra-departmental differences in regard to their experience. This is well demonstrated by the fact that reported annual student enrollment varied quite considerably across individual courses and institutions with some departments reporting annual enrollments in the hundreds and others in single digits. Differing amounts of years of experience with courses of this type as well as in the way faculty were prepared and assigned to teach these courses were also reported.

Several potentially fruitful opportunities for future research in this area present themselves. A comparison of the characteristics of institutions and their activity in regard to leadership and HRM/D course offerings would help to illuminate the impact of institutional or departmental factors which impact course offerings of this type. Of interest and benefit would be a comprehensive consideration of course content and curriculum, possible comparing course contents to determine what, if any, differences there are between leadership and HRM/D courses offered through agricultural education departments and those offered through other academic departments.

In general, this mostly quantitative account of leadership and HRM/D courses offered through departments of agricultural education is a positive one. From a market perspective, leadership and HRM/D courses offered through departments of agricultural education appear to be a product which enjoys substantial consumer satisfaction and meets a well established, and in some cases, growing demand. Decisions by individual departments to either begin or to expand course offerings in this area will certainly depend upon the unique characteristics of their department and their institution; however, the aggregate experience of other departments of agricultural education provides positive encouragement in that regard.

\section{References}

Agricultural educators directory. (1992). Greenburg, PA: Henry.

B lock, P. (1990). Th e e m -

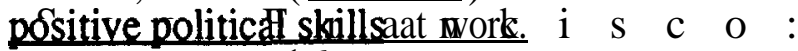
Jossey-Bass, p. 16.

Brannon, T., Holley, C.W. and Key, J.P. Impact of vocational agriculture/FFA on community leadership. Journal of Agriculture Ed-, 30(3): $37-45$.

Carnevale, A.P., Gainer, L.J., and Villet, J. (1990). Training in America. San Francisco: Jossey-Bass.

Cox, D.E. (1985, May). Leadership development internship. The Agricultural Education Magazine, pp. 20-21.

Dodge, G. and Foster, R. Interpersonal skill development instruction for colleges of agriculture. National Association of College and Teachers of Agriculture Journal, $\mathrm{B}(2)$ : 2629.

Gilley, J.W. and Eggland, S.A. (1989). Principles of human resource develooment. Manchester, MA: Addison-Wesley, PP. 2-8.

London, M. (1989). Managimg the training enterpnse. San Francisco: Jossey-Bass, pp. 254-258.

National Summit on Agricultural Education. (1989). The strategy plan for agricultural education, Alexandria, VA. The National Council for Agricultural Education, p. 4.

Objectives for vocational-technical education in agriculture. (1976). U.S. Office of Education Bulletin. No. 4. Washington, D.C.: United States Government Printing Office, p. 4.

Powers, L. and Walson, F. (1991, June). "Agricultural education: first twenty-five years of the third millennium." The Agricultural Educainon Míagazıne, p $9-11$.

Whaley, D.C. (Compiler). (1992). Directory of leacher educators in agriculture. Washington, D.C.: U.S. Department of Education in cooperation with the American Association for Agricultural Education. 